AperTO - Archivio Istituzionale Open Access dell'Università di Torino

\title{
Palbociclib inhibits proliferation of human adrenocortical tumor cells.
}

\section{This is the author's manuscript}

Original Citation:

Availability:

This version is available http://hdl.handle.net/2318/1687237

since 2019-04-26T10:52:19Z

Published version:

DOI:10.1007/s12020-017-1270-0

Terms of use:

Open Access

Anyone can freely access the full text of works made available as "Open Access". Works made available under a Creative Commons license can be used according to the terms and conditions of said license. Use of all other works requires consent of the right holder (author or publisher) if not exempted from copyright protection by the applicable law. 


\section{IIIS AperTO}

UNIVERSITÀ DEGLI STUDI DI TORINO

This is the author's final version of the contribution published as:

Fiorentini C, Fragni M, Tiberio GAM, Galli D, Roca E, Salvi V, Bosisio D, Missale C, Terzolo M, Memo M, Berruti A, Sigala S.

Palbociclib inhibits proliferation of human adrenocortical tumor cells.

Endocrine; 59(1):213-217; 2018; DOI: 10.1007/s12020-017-1270-0.

The publisher's version is available at:

https://link.springer.com/article/10.1007\%2Fs12020-017-1270-0

When citing, please refer to the published version.

Link to this full text:

https://link.springer.com/content/pdf/10.1007\%2Fs12020-017-1270-0.pdf 


\section{PALBOCICLIB INHIBITS PROLIFERATION OF HUMAN ADRENOCORTICAL TUMOR CELLS}

Chiara Fiorentini $^{1 \#}$, Martina Fragni ${ }^{1 \#}$, Guido A.M. Tiberio ${ }^{2}$, Diego Galli ${ }^{1}$, Elisa Roca ${ }^{3}$, Valentina Salvi ${ }^{4}$, Daniela Bosisio $^{4}$, Cristina Missale ${ }^{1}$, Massimo Terzolo ${ }^{5}$, Maurizio Memo ${ }^{1}$, Alfredo Berruti $^{3}$, Sandra Sigala $^{1}$

\section{Affiliation:}

${ }^{1}$ Section of Pharmacology, Department of Molecular and Translational Medicine, University of Brescia, V.le Europa 11, 25123 Brescia, Italy;

${ }^{2}$ Surgical Clinic, Department of Clinical and Experimental Sciences, University of Brescia at Asst Spedali Civili di Brescia, P.le Spedali Civili 1, 25123 Brescia, Italy,

${ }^{3}$ Oncology Unit, Department of Medical and Surgical Specialties, Radiological Sciences, and Public Health, University of Brescia at Asst Spedali Civili di Brescia, P.le Spedali Civili 1, 25123 Brescia, Italy;

4 Section of Oncology and Experimental Immunology, Department of Molecular and Translational Medicine, University of Brescia, V.le Europa 11, 25123 Brescia, Italy;

${ }^{5}$ Internal Medicine 1, Department of Clinical and Biological Sciences, University of Turin at San Luigi Hospital, Regione Gonzole 10, 10043 Orbassano, Italy;

\section{\# These Authors equally contributed to this work}

Key terms: adrenocortical carcinoma, human, Palbociclib, retinoblastoma, CDK4/6

\section{Corresponding author:}

Prof. Alfredo Berruti

U.O. Oncology

University of Brescia and A.S.S.T. Spedali Civili di Brescia

P.le Spedali Civili 1, 25123 Brescia, Italy;

Email: alfredo.berruti@gmail.com

Acknowledgments: This work was supported by University of Brescia local grants; AIRC, project IG17678; Fondazione Camillo Golgi and by a private donation of Mrs Serena Ambrogini and family in memory of her son Guido Cioni.

M.F. was supported by a grant from the Italian Society of Pharmacology.

\section{iris-AperTO}


Palbociclib was kindly provided by Pfizer. 


\section{Introduction}

Adrenocortical cancer (ACC) is a rare malignant tumor [1]. Pharmacological therapy is based on mitotane administered alone or in association with the EDP regimen (etoposide, doxorubicin and cisplatin) [1]. However, the prognosis of ACC patients not amenable to surgery still remains poor and newer treatment strategies are needed [2]. Drugs targeting cell cycle could be a relevant new therapeutic approach for patients with advanced ACC [3].

Cell cycle is controlled by several key proteins, including CDKs (cyclin-dependent kinases), which are the target of recently discovered cell-cycle checkpoint inhibitors. [4]. Palbociclib is a CDK4/6-inhibitor that is active against a broad range of tumors and has an acceptable toxicity, being neutropenia being the most relevant side effect [5]. This drug is actually approved in the management of locally advanced or metastatic breast cancer [6].

In this study, we investigated in vitro the effect of Palbociclib in NCI-H295R ACC cells and human ACC primary cultures. 


\section{Methods}

Cell line. NCI-H295R cell line was obtained from the American Type Culture Collection (ATCC) and cultured as suggested.

Primary cell cultures. Human ACC primary cells were derived from surgical specimens of ACC patients after obtaining a written informed consent. They were identified by a sequential number, based on the date of surgery. The project was approved by the local Ethical Committee. ACC02 cell culture derived from a steroid-secreting ACC; whereas ACC03, ACC06 and ACC08 cell cultures derived from non-secreting ACC. After surgical removal, cells were enzymatically digested with collagenase and cultured in the same medium of NCI-H295R cells.

Quantitative RT-PCR (qRT-PCR). Gene expression was evaluated by qRT-PCR (ViiA7, Applied Biosystems), using the SYBR Green as fluorochrome, as described [7]. Primer sequences are shown in Fig.1 (panel A).

Cell viability assay. ACC cells were treated up to for 4 days with palbociclib $(1 \mathrm{nM}-1 \mu \mathrm{M})$, solubilized in water. Cell viability was determined by 3-(4,5-Dimethyl-2-thiazol)-2,5-diphenyl-2H-tetrazolium bromide (MTT) dye reduction assay [8]. Absorbance was determined by a spectrophotometer at 540/620 nm (GDV).

Cell cycle analysis. Flow cytometric cell cycle analysis was performed as described [9]. Untreated and treated-NCIH295R cells were fixed, treated with RNase A $(12.5 \mu \mathrm{g} / \mathrm{ml})$, stained with Propidium iodide (40 $\mu \mathrm{g} / \mathrm{ml})$ and analyzed by Flow Cytometry using a MACS Quant Analyzer (Miltenyi Biotec GmbH) for cell cycle status. Data were analyzed using FlowJo (TreeStar).

Western Blot. ACC cell lysates were processed as described [8]. The following primary antibodies were used: Rb protein (pRB) (DB Pharmigen; $2.5 \mu \mathrm{g} / \mathrm{mL}$ ), CDK4 or CDK6 kinase (Santa Cruz Biotechnologies; both at $1 \mu \mathrm{g} / \mathrm{mL}$ ), cyclin D1 (Cell Signalling; $0.1 \mu \mathrm{g} / \mathrm{mL}$ ), p107 and p130 (Santa Cruz Biotechnologies, both at $1 \mu \mathrm{g} / \mathrm{mL}$ ) and tubulin (Sigma Aldrich; $0.01 \mu \mathrm{g} / \mathrm{mL}$ ). The specific signal was visualized and the densitometric analysis was performed using the GelPro-Analyzer version 6.0 (MediaCybernetics).

Statistical analysis. Data analysis was conducted using GraphPad Prism 5 software (GraphPad Software). Statistical analysis was carried out using one-way ANOVA and Bonferroni’s Multiple Comparison test. A p value $<0.05$ was considered as statistically significant. 


\section{Results}

CDK 4/6 and Rb protein (pRb) expression. The mRNAs encoding for CDK4/6 and pRb were examined in both NCIH295R cells and ACC primary cultures using qRT-PCR. Differences in the threshold cycle (Ct) value between the $\beta-$ actin housekeeping gene and CDK4, CDK6 and Rb genes $(\Delta \mathrm{Ct})$ were calculated, as an index of the amount of mRNA expressed. Both NCI-H295R cells and ACC primary cultures expressed high amount of mRNA encoding CDK4/6. $\mathrm{pRb}$ mRNA was highly detected in ACC primary cultures while it was almost undetectable in NCI-H295R cells (Fig.1a). CDK4, CDK6 and pRb were then analyzed by Western Blot, showing that both the CDK kinases were equally expressed. The $\sim 106 \mathrm{KDa}$ band, corresponding to the predicted molecular weight of pRb, was detected in ACC02, ACC03 and ACC06 primary cells, but it was almost absent in NCI-H295R and ACC08 cells (Fig.1b).

Effect of Palbociclib on NCI-H295R cells and ACC primary cultures cell viability. The MTT assay revealed that Palbociclib induced a concentration-dependent decrease of cell viability in each cell culture (Fig.1c).

Effect of Palbociclib on NCI-H295R cell cycle. NCI-H295R cells were then treated with the Palbociclib IC $_{50}$ and the cell cycle distribution was analyzed by flow cytometry at different times. Results indicated an increase in the proportion of cells at the G0/G1 phase after 48 hours of treatment (untreated cells: $51.3 \% \pm 1.5$; Palbociclib-treated cells: $60.8 \% \pm 6.7$ ), that was maintained at 72 hours (untreated cells: $47.4 \% \pm 0.2$; Palbociclib-treated cells: $59.5 \% \pm 5.1$ ). Furthermore, Palbociclib significantly decreased the expression levels of the cell cycle-related proteins cyclin D1 $(34 \% \pm 2,3$ and $46 \% \pm 1,1$ of reduction, at 48 and 72 hours of treatment, respectively, $p<0.001)$ (Fig $1 \mathrm{~d})$, consistent with a G0/G1 cell cycle arrest [10]. CDK4/6 expression did not change after treatment both at mRNA and protein level of (data not shown). Interestingly, a $130 \mathrm{kDa}$ band, likely corresponding to the p130/RBL2 Rb-like family protein [11,12], was clearly detected in NCI-H295R cells (Fig.1e).

\section{Discussion}

This study explored for the first time the in vitro activity of the CDK4/6 antagonist Palbociclib in ACC, using the commercially available NCI-H295R cell line and primary cultures derived from ACC patients.

It is known that CDK4/6 inhibition by Palbociclib correlates with greater CDK4/6 inhibitor therapeutic activity, whereas the loss of RB1 is linked to CDK inhibitor resistance [4]. Inactivating mutations or homozygous deletions of the $R B 1$ gene were found in $7 \%$ of ACC $[13,14]$, indicating that a small proportion of ACC may be potentially resistant to CDK4/6 inhibitors. In this study, while NCI-H295R cells and all the primary ACC cells expressed CDK4 and CDK6, $\mathrm{pRb}$ protein was found in 3 out of 4 ACC primary cultures. In the ACC08, in fact, only the pRb transcript was clearly 
detected, suggesting the presence of a mutation in the translational mechanisms of this protein. In addition, both $\mathrm{pRb}$ mRNA and protein were hardly detected in NCI-H295R cells.

Palbociclib significantly affected cell viability in a concentration-dependent way in all ACC cells used in this study, although with a different sensitivity. Overall, the $\mathrm{IC}_{50}$ values obtained were close to the $\mathrm{Cmax}$ of about $51 \mathrm{ng} / \mathrm{ml}$ measured after one single dose of $125 \mathrm{mg}$ Palbociclib in humans [15], corresponding to $0.11 \mu \mathrm{M}$. Flow cytometric analysis revealed that Palbociclib treatment lead to cell accumulation in G0/G1 phase in NCI-H295R cells, combined with a significant decrease of cyclin D1 levels, while CDK4/6 expression was unchanged. These data confirm also in ACC cells that the cell cycle arrest is likely the main mechanism of the cytotoxic effect of Palbociclib [10].

Interestingly, despite the lack of pRb expression, both NCI-H295R cells and ACC08 primary culture were sensitive to the anti-tumoral effect of Palbociclib. It is well known that $\mathrm{pRb}$ is just one of the multiple targets of the CDK4/6/Cyclin D pathway [11] and a Rb-like family including p107/RBL1 and p130/RBL2 proteins (all substrates for CDK/6 inhibitors) was identified [12]. One of these proteins (p130/RBL2) was detected in NCI-H295R cells in this study. A recent study showed that $\mathrm{pRb}$ negative human hepatoma cell lines are sensitive to palbociclib due the expression of both p107/RBL1 and p130/RBL2 [16].

Several molecular targets have been recently identified for novel treatment approaches in the management of ACC, including mTOR [17,18], Wnt-beta catenin signaling pathway [13], receptors for different growth factors and the ACAT1 [2] and CYP17A1 [19] steroidogenic enzymes.

In this study, we provide a preclinical preliminary evidence that CDK4/6 targeting agents could be effective in the ACC treatment, irrespective $\mathrm{pRb}$ expression. Palbociclib, whose toxicity profile seems to be advantageous over the EDP regimen [20], deserves to be further explored as a new therapeutic option in ACC.

\section{Compliance with ethical standards}

Conflict of interest: The authors declare that they have no conflict of interest in relation to the topic of the manuscript

Funding: This work was supported by University of Brescia local grants; AIRC, project IG17678; Fondazione Golgi and a private donation of Mrs Serena Ambrogini and family in memory of her son Guido Cioni.

Ethical approval: The project was approved by the local Ethical Committee.

Informed consent: Informed consent was obtained from all individual participants included in the study. 


\section{References}

1. Berruti, A., Baudin, E., Gelderblom, H., Haak,H.R., Porpiglia, F., Fassnacht, M., Pentheroudakis, G., ESMO Guidelines Working Group: Adrenal cancer: ESMO Clinical Practice Guidelines for diagnosis, treatment and follow-up. Ann Oncol. Suppl 7:vii131-8 (2012)

2. Hoff, A.O., Berruti, A.: Hormone and Cancer 5th International ACC Symposium: Future and Current Therapeutic Trials in Adrenocortical Carcinoma. Horm Cancer. 7, 29-35 (2016)

3. De Martino, M.C., Al Ghuzlan, A., Aubert, S., Assié, G., Scoazec, J.Y., Leboulleux, S., Do Cao, C., Libè, R., Nozières, C., Lombès, M., Pattou, F., Borson-Chazot, F., Hescot, S., Mazoyer, C., Young, J., Borget, I., Colao, A., Pivonello, R., Soria, J.C., Bertherat, J., Schlumberger, M., Lacroix, L., Baudin, E.: Molecular screening for a personalized treatment approach in advanced adrenocortical cancer. J Clin Endocrinol Metab. 98, 4080-8 (2013)

4. Hamilton, E., Infante, J.:Targeting CDK4/6 in patients with cancer. Cancer Treat Rev. 45, 129-38 (2016)

5. Dickson, M.A.: Molecular pathways: CDK4 inhibitors for cancer therapy. Clin Cancer Res. 20, 3379-83 (2014)

6. Verma, S., Bartlett, C.H., Schnell, P., DeMichele, A.M., Loi, S., Ro, J., Colleoni, M., Iwata, H., Harbeck, N., Cristofanilli, M., Zhang, K., Thiele, A., Turner, N.C., Rugo, H.S.: Palbociclib in Combination With Fulvestrant in Women With Hormone Receptor-Positive/HER2-Negative Advanced Metastatic Breast Cancer: Detailed Safety Analysis From a Multicenter, Randomized, Placebo-Controlled, Phase III Study (PALOMA-3). Oncologist. pii: theoncologist.2016-0097 (2016)

7. Sigala, S., Bodei, S., Missale, C., Zani, D., Simeone, C., Cunico, S.C., Spano, P.F.: Gene expression profile of prostate cancer cell lines: effect of nerve growth factor treatment. Mol Cell Endocrinol. 1284, 11-20 (2008)

8. Fiorentini, F., Bodei, S., Bedussi, F., Fragni, M., Bonini, S.A., Simeone, C., Zani, D., Berruti, A., Missale, C., Memo, M., Spano, P.F., Sigala, S.: GPNMB/OA protein increases the invasiveness of human metastatic prostate cancer cell lines DU145 and PC3 through MMP-2 and MMP-9 activity. Exp Cell Res. 323, 100-11 (2014)

9. Casaburi, I., Avena, P., De Luca, A., Chimento, A., Sirianni, R., Malivindi, R., Rago, V., Fiorillo, M., Domanico, F., Campana, C., Cappello, AR., Sotgia, F., Lisanti, MP., Pezzi, V.: Estrogen related receptor $\alpha$ $(\mathrm{ERR} \alpha)$ a promising target for the therapy of adrenocortical carcinoma (ACC). Oncotarget. 22, 25135-48 (2015) 
10. Roskoski, R.: Cyclin-dependent protein kinase inhibitors including palbociclib as anticancer drugs. Pharmacol Res. 107, 249-75 (2016)

11. Dyson, N.J.: RB1: a prototype tumor suppressor and an enigma. Genes Dev. 30, 1492-502 (2016)

12. Malumbres, M., Barbacid M.: Mammalian cyclin-dependent kinases. Trends Biochem Sci. 30, 630-41 (2005)

13. Assié, G., Letouzé, E., Fassnacht, M., Jouinot, A., Luscap, W., Barreau, O., Omeiri, H., Rodriguez, S., Perlemoine, K., René-Corail,F., Elarouci, N., Sbiera, S., Kroiss, M., Allolio, B., Waldmann, J., Quinkler, M., Mannelli, M., Mantero, F., Papathomas, T., De Krijger, R., Tabarin, A., Kerlan, V., Baudin, E., Tissier, F., Dousset, B., Groussin, L., Amar, L., Clauser, E., Bertagna, X., Ragazzon, B., Beuschlein, F., Libé, R., de

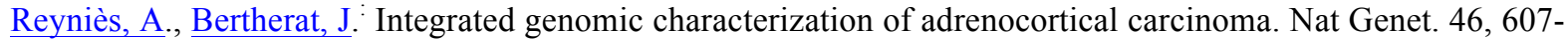
$12(2014)$

14. Ragazzon, B., Libé, R., Assié, G., Tissier, F., Barreau, O., Houdayer, C., Perlemoine, K., Audebourg, A., Clauser, E., René-Corail, F., Bertagna, X., Dousset, B., Bertherat, J., Groussin, L.: Mass-array screening of frequent mutations in cancers reveals RB1 alterations in aggressive adrenocortical carcinomas. Eur J Endocrinol. 170, 385-91 (2014)

15. Hoffman, J.T., Plotka, A., O’Gorman, M., Chang, A., Kosa, M., Loi C.M.,. Gallo-Stampino, C., Wang, D.D.: A phase 1 randomized, open-label, fixed-sequence, 2-period study of the effect of multiple doses of rifampin on palbociclib (PD-0332991) pharmacokinetics in healthy volunteers. ASCO Annual Meeting, Philadelphia, 18$22,(2015)$

16. Rivadeneira, D.B., Mayhew, C.N., Thangavel, C., Sotillo, E., Reed, C.A., Graña, X., Knudsen, E.S.: Proliferative suppression by CDK4/6 inhibition: complex function of the retinoblastoma pathway in liver tissue and hepatoma cells. Gastroenterology. 138, 1920-30 (2010)

17. Fraenkel, M., Gueorguiev, M., Barak, D., Salmon, A., Grossman, A.B., Gross, D.J.: Everolimus therapy for progressive adrenocortical cancer. Endocrine. 44, 187-192 (2013)

18. De Martino, M.C., van Koetsveld, P.M., Feelders, R.A., Lamberts, S.W., de Herder, W.W., Colao, A., Pivonello, R., Hofland, L.J.: Effects of combination treatment with sirolimus and mitotane on growth of human adrenocortical carcinoma cells. Endocrine. 52, 664-667 (2016) 
19. Fiorentini, C., Fragni, M., Perego, P., Vezzoli, S., Bonini, SA., Tortoreto, M., Galli, D., Claps, M., Tiberio, GA., Terzolo, M., Missale, C., Memo, M., Procopio, G., Zaffaroni, N., Berruti, A., Sigala, S.: Antisecretive and Antitumor Activity of Abiraterone Acetate in Human Adrenocortical Cancer: A Preclinical Study. J Clin Endocrinol Metab. 101, 4594-4602 (2016)

20. Berruti, A., Terzolo, M., Sperone, P., Pia, A., Della Casa, S., Gross, D.J., Carnaghi, C., Casali, P., Porpiglia, F., Mantero, F., Reimondo, G., Angeli, A., Dogliotti, L.: Etoposide, doxorubicin and cisplatin plus mitotane in the treatment of advanced adrenocortical carcinoma: a large prospective phase II trial. Endocr Relat Cancer. 12, 657-666 (2005) 
Fig.1 Gene expression of CDK4/6 and pRb in NCI-H295R cells and ACC primary cultures. a, Aliquots of each cDNA, chosen after standard curves experiments, were used in $25 \mu 1$ reaction containing $12.5 \mu 1$ SYBR Green Mix (Bio-Rad Laboratories) and $12.5 \mathrm{pmol}$ each of sense and antisense oligonucleotide primers of selected genes and human $\beta$-actin as reference gene. Reactions were performed under the following conditions: 1 cycle $95^{\circ} \mathrm{C}$ for $10 \mathrm{~min}, 40 \mathrm{cycles}$ at $95^{\circ} \mathrm{C}$ for $15 \mathrm{~s}, 60^{\circ} \mathrm{C}$ for $1 \mathrm{~min}$. Results are presented as a mean $\Delta \mathrm{Ct} \pm \mathrm{SEM}$. b, Analyses of CDK4, CDK6 and pRb expression of NCI-H295R cells and ACC primary cultures. Lysates from NCI-H295R cells (line 1) and primary cultures of ACC03 (lane 2) ACC02 (lane 3), ACC08 (lane 4) and ACC06 (lane 5) were analysed for CDK4, CDK6 and $\mathrm{Rb}$ protein $(\mathrm{pRb})$ expression by using Western Blot technique. The human $\alpha$-tubulin was used as internal control. The specific signal was visualized by the ECL-PLUS system. c, Effect of Palbociclib on NCI-H295R cells and ACC primary cultures cell viability. ACC cells were treated as described in Methods. Results are expressed as percent of viable cells versus untreated cells (control) \pm SEM of at least three different experiments, run in triplicate. NCI-H295R cell line, ACC03, ACC08 and ACC06: for concentrations starting from $250 \mathrm{nM}$ to $1 \mu \mathrm{M},{ }^{*} p<0.001$ vs.untreated cells; ACC02: for concentrations starting from $500 \mathrm{nM}$ to $750 \mathrm{nM}, \# p<0.01$ vs.untreated cells, and for $1 \mu \mathrm{M}$ concentration, ${ }^{*} p<0.001$ vs.untreated cells. $\mathrm{IC}_{50}$ value were: $0.84 \mu \mathrm{M}(95 \% \mathrm{CI}: 0.4-1.7)$ for NCI-H295R cells, $0.67 \mu \mathrm{M}(95 \%$ CI: $0.66-$ $0.69)$ for $\mathrm{ACC} 02,0.29 \mu \mathrm{M}(95 \% \mathrm{CI}: 0.15-0.57)$ for $\mathrm{ACC} 03,0.50 \mu \mathrm{M}(95 \% \mathrm{CI}: 0.28-0.88)$ for $\mathrm{ACC} 06$, and $0.18 \mu \mathrm{M}$ (95\% CI: 0.10-0.32) for ACC08. d, Cyclin D1 expression in untreated and Palbociclib-treated NCI-H295R cells. Cells were treated with palbocilcib and analysed for cyclin D1 using Western Blot technique. The human $\alpha$-tubulin was used as internal control. The specific signal was visualized by the ECL-PLUS system. e, Analyses of p107/RBL1 and p130/RBL2 expression in NCI-H295R cells. Lysates from NCI-H295R cells were analysed for p107/RBL1 and p130/RBL2 expression by using Western Blot technique. The human $\alpha$-tubulin was used as internal control. The specific signal was visualized by the ECL-PLUS system. 